\title{
Diversity in Collection Development: Comparing Access Strategies to Alternative Press Periodicals
}

\section{Deborah M. LaFond, Mary K. Van Ullen, and Richard D. Irving}

This study compares methods of providing access to diverse points of view as represented by journals indexed in Alternative Press Index (API). To determine University at Albany patron access to nonmainstream periodicals, local print subscriptions, expedited interlibrary loan through resource-sharing consortia, and electronic full-text packages were compared to periodicals listed in $\mathrm{API}$. Electronic full-text packages provide some added access to nonmainstream journals. However, much greater access was found to be provided by participation in resource-sharing networks.

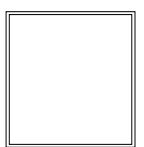

roviding access to nonmainstream periodical literature is consistent with the library profession's advocacy of diver-

sity in collection development. ${ }^{1}$ Yet, recent studies have demonstrated that academic libraries have had limited success in meeting this standard. ${ }^{2}$ Economic constraints resulting from escalating periodical subscription prices have further eroded academic libraries' ability to subscribe to nonmainstream titles. Association of Research Library (ARL) data indicate that "while ARL libraries more than doubled expenditures for serials from 1986-1997, they bought $6 \%$ fewer serial titles." ${ }^{3}$ Nonmainstream titles are likely to suffer disproportionately in this environment because they do not fare well in terms of the criteria frequently used to justify pe- riodical subscriptions (i.e., coverage in major indexing and abstracting services, high citation rates, and high use rates). This article compares the efficacy of various strategies for providing access to nonmainstream periodicals. In it, the authors examine and compare the traditional local subscription approach, resource-sharing consortia that include expedited interlibrary loan (ILL) systems, and four electronic full-text periodical products to determine which ones offer the greatest potential for providing access.

\section{Diversity in Collections}

ALA's position statement "Diversity in Collection Development" is based on Article II of the Library Bill of Rights, which holds that "Libraries should provide materials and information presenting all points of

Deborah M. LaFond is the Social Sciences Bibliographer at the University at Albany, SUNY; e-mail: dlafonde@cnsvax.albany.edu. Mary K. Van Ullen is the Business and Economics Bibliographer at the University at Albany, SUNY; e-mail: vanullen@cnsvax.albany.edu. Richard D. Irving is the Bibliographer for Public Affairs and Policy in the Dewey Graduate Library for Public Affairs and Policy at the University at Albany, SUNY; e-mail: RDI34@cnsvax.albany.edu. 
view on current and historical issues. Materials should not be proscribed or removed because of partisan or doctrinal disapproval." ${ }^{4}$ To avoid making the librarian any kind of censor or 'validator of opinion,' ALA adopted a new collection development policy statement in 1989, changing the focus from one based on balanced collections to one of diversity in collection development. In applying this statement, ALA has moved away from the "balanced" selection criterion because it could be "misunderstood to presuppose a bias toward moderation and to place limitations on the acquisi-

\section{The intent of Empire Express is to cut in half the normal turnaround time for ILL requests.}

tion of materials thought to be 'extreme,' because these might skew the 'balance' of the collection." ${ }^{\prime 5}$ Instead, ALA has promoted a "diversity" selection criterion that obliges the library to include not only many different views in a collection, but also "materials representing the broadest diversity of human thought and creativity." ${ }^{16}$ Implicit in this statement is the recognition that libraries should collect materials not just representative of dominant societal viewpoints, but also of the views of historically underrepresented groups within society. The diversity construct also is consistent with principles of academic freedom that encourage an inclusive approach open to entertaining even the most controversial ideas and theories. ${ }^{7}$

\section{Evaluating Diversity of Periodical Collections}

In exploring balance in periodical collections, several recent studies have examined whether there is a conservative or liberal bias in library periodical collections. ${ }^{8}$ However, as indicated above, assessing balance is only part of what contributes to diversity in a collection. Bias studies that only contrast conservative and liberal viewpoints or major opposing viewpoints held in a collection do not sufficiently address alternative, or nonmainstream, views.
Few recent articles have evaluated academic periodical collections using the broader diversity criterion. In a study of Canadian academic libraries, Juris Dilevko and Kalina Grewal found that libraries were much more likely to subscribe to "corporate public opinion" journals (representing mainstream views), than "non-corporate public opinion" journals (representing non-mainstream views) $)^{9}$ Rita A. Marinko and Kristin $\mathrm{H}$. Gerhard published a recent study that examined the diversity of journal collections in academic libraries. In their study, Marinko and Gerhard sought to find out how widely Alternative Press Index (API) journal titles are held by U.S. ARL libraries. API is produced by the Alternative Press Center, which describes itself as a nonprofit collective dedicated to providing access to, and public awareness of, the alternative press. API covers many popular and academic periodicals, newspapers, and magazines not indexed in either the Reader's Guide to Periodical Literature or the Social Sciences Index. ${ }^{10}$ Marinko and Gerhard found that although 88 percent of the ARL libraries subscribed to $A P I$, individual ARL libraries were considerably less likely to subscribe to the titles indexed in API. ${ }^{11}$

\section{Research Questions}

Marinko and Gerhard asked: How well are academic libraries meeting the need for scholarly access to alternative press titles? ${ }^{12}$ They attempted to answer this question by examining the extent to which academic libraries subscribed to titles indexed in API. This study expands on Marinko and Gerhard's findings by investigating whether subscription to commercial electronic full-text journal packages combined with resource-sharing consortia has the potential to significantly augment access to nonmainstream periodical titles. Because traditional ILL does not offer quick enough turnaround time to satisfy many users, this study looked at access to API titles through expedited ILL resource-sharing consortia within the State University of New York 
(SUNY). The expedited ILL services considered here are Empire Express and SUNYConnect.

\section{Empire Express}

The University at Albany, a SUNY institution, currently belongs to Empire Express. Other members of this expedited ILL service are the State University of New York at Buffalo, at Binghamton, and at Stony Brook, and Syracuse University. Syracuse University, although a participant in Empire Express, is not a SUNY institution. The intent of Empire Express is to cut in half the normal turnaround time for ILL requests. Persons affiliated with any of the Empire Express institutions can expedite an ILL request by checking the online catalog of any of the other four institutions and verifying that another member's library owns a particular item. Patrons then attach the holdings information to an ILL request submitted to the host library.

\section{SUNYConnect}

The State University of New York is currently developing another consortium called SUNYConnect. ${ }^{13}$ The cornerstone of this proposed system would be an integrated Web-based catalog that would provide access to the holdings of all seventyone SUNY academic libraries, including the University at Albany (UA) libraries. If fully implemented, SUNYConnect could provide faculty and staff with expedited retrieval of materials from any library within the SUNY system.

\section{Methodology}

As the universe of titles for this study, the authors selected the 290 periodicals indexed in API taken directly from its Web page. ${ }^{14}$ The principal considerations leading to the decision to use this particular universe of titles were that API's specific intent is to provide bibliographic references to nonmainstream periodicals. The purpose of this study is to examine the accessibility of nonmainstream journals, rather than potential bias within the universe of titles in API or within the genre of nonmainstream, alternative periodicals. Also, API is widely held by academic libraries and serves as a key tool for indexing nonmainstream materials.

Three methods of providing access to the current content of the 290 periodicals were investigated and compared. First, it was determined whether the UA libraries had a current print subscription for each title in API by searching the library catalog. This provided a measure of the most traditional means of access. The UA libraries discussed in this paper include the university library, the newly opened science library on the uptown campus, and the Thomas E. Dewey Graduate Library for Public Affairs and Policy on the Rockefeller College campus.

Second, the 290 titles were compared against a merged source list taken from four electronic vendors who provide full-text journal articles. The electronic databases selected were Lexis-Nexis Academic Universe, EBSCO Academic Search FullTEXT Elite, Expanded Academic ASAP, and ProQuest Direct Research Library. All four of these services provide access to some full-text articles from periodicals covering a broad range of subject areas and are designed for academic users. Only titles that were represented as full-text by the source list were counted.

The third method of availability investigated was access to current print subscriptions of API titles within SUNY libraries. To determine holdings within these libraries and Syracuse University libraries, the authors searched the ILL subsystem of the OCLC database for records corresponding to the titles indexed in API. The search was done by international standard serial number (ISSN) or by title if no ISSN was available. If a search produced multiple records, each record was examined to determine which libraries maintained current subscriptions for each title.

The ILL department at the University at Albany uses the OCLC "custom holdings package." This feature allows the institution to create user-defined library groups, which facilitated identification of the libraries in New York State that had 


\begin{tabular}{|lccc|}
\hline \multicolumn{4}{c|}{$\begin{array}{c}\text { TABLE 1 } \\
\text { Coverage of } \boldsymbol{A P I} \text { Title in Full-Text Databases }\end{array}$} \\
\hline \hline Database & $\begin{array}{c}\text { No. of } \\
\text { APITitles }\end{array}$ & $\begin{array}{c}\text { \%o of } \\
\text { TPI Titles }\end{array}$ & $\begin{array}{c}\text { Titles in Addition to } \\
\text { UA Library Holdings }\end{array}$ \\
\hline $\begin{array}{l}\text { EBSCO Academic } \\
\text { Search FullTEXT Elite } \\
\text { Expanded Academic } \\
\text { ASAP }\end{array}$ & 34 & 12.0 & 20 \\
$\begin{array}{l}\text { Lexis-Nexis Academic } \\
\text { Universe }\end{array}$ & 17 & 12.3 & 19 \\
ProQuest Direct & 23 & 6.0 & 12 \\
\hline
\end{tabular}

current subscriptions to each title. The command "dhc" allowed the authors to restrict the holdings information to library symbols included in the custom holdings. This list of three-letter symbols was then compared against a list of three-letter symbols for SUNY and Empire Express libraries. If one of the symbols was present, the command "dhu" was entered to determine whether the library maintained a current subscription to the title. The command "set hp ser" must be entered prior to "dhu" in order to access the union list information. The "set hp ser" command does not have to be entered for each title but, rather, just once at the beginning of each search session. This process enabled the authors to determine which, if any, of the SUNY li-

There was some overlap in content between these full-text products and the UA libraries' own holdings.

braries maintained a current print subscription. A few SUNY libraries are not included in the authors' custom holdings. For these remaining libraries, the authors checked for holdings in the state by using a "dhs" command and then looked for their symbols. If one of their symbols appeared, it was determined whether that library maintained a current subscription by entering the union list command "ulnyul."

Given that the authors were interested to learn how well the SUNY system libraries or Syracuse University libraries provided access to these titles, all the OCLC holding statement information for each title was copied as it appeared in OCLC records into a separate electronic file. The file then was reviewed to discover which libraries held current subscriptions to API titles. A title was counted as being present in the consortia if held by one of the member libraries. Separate counts were done for libraries within the Empire Express and SUNYConnect systems. In these counts, UA holdings were excluded from the OCLC counts. Data were recorded in an EXCEL spreadsheet.

\section{Results}

Of the 290 titles listed on the API Web site source list, it was discovered that six had ceased publication. Because this study only considered current subscriptions, these titles were eliminated from the analysis and the calculations were based on a universe of 284 titles. Examination of the UA libraries' online catalog revealed that they currently subscribe to sixty-two $(21.8 \%)$ of the titles indexed in API. Another eight titles (2.8\%) had been held by the libraries in the past but had been canceled at some point.

Four full-text electronic database products were examined for coverage of API titles by using the source lists published by the vendors. The results are summarized in table 1 . The database package having the highest number of API titles was Expanded Academic ASAP, with thirtyfive titles $(12.3 \%)$, followed closely by EBSCO Academic Search FullTEXT Elite, with thirty-four titles (12.0\%). ProQuest Di- 
rect covered twenty-three API titles (8.1\%), and Lexis-Nexis Academic Universe included seventeen titles (6.0\%).

There was some overlap in content between these full-text products and the UA libraries' own holdings. If these products are considered as a means to increase access to API titles for UA patrons, it is useful to look at the number of additional titles that are potentially available beyond currently held print subscriptions at the UA libraries. As the last column in table 1 shows, EBSCO Academic Search FullTEXT Elite included twenty additional titles beyond those held at the University at Albany, followed by Expanded Academic ASAP, with nineteen additional titles. Both ProQuest Direct and Lexis-Nexis Academic Universe provided twelve titles beyond UA's own holdings.

Of the 284 active API titles, only fiftysix $(19.7 \%)$ were available full text in any of the four products examined. However, if a title was available in any one of the electronic sources included in the study, there was a reasonably good chance it was covered by more than one of the products. Thirty-three of the 284 API titles $(11.6 \%)$ appeared in more than one of the four full-text databases. More than half of the fifty-six titles that were available electronically $(58.9 \%)$ were in more than one product. There was a great deal of overlap in coverage between the two products having the most full-text coverage for API titles, with nineteen titles available in both Expanded Academic ASAP and EBSCO Academic FullTEXT Elite, which is more than half of the API titles carried by either product.
The authors searched the OCLC database to determine the availability of API titles within both the currently operating Empire Express and the planned SUNYConnect system. These results are summarized in table 2. In this table, the authors did not count titles held by the university libraries when deciding whether a title was in the SUNYConnect or Empire Express systems but, rather, only counted the title if one of the other participant libraries had a current subscription.

Table 2 shows that Empire Express libraries held current print subscriptions for 135 API titles $(47.5 \%$ of the 284 API titles). Of those, seventy-eight titles were not duplicated by the UA libraries' holdings. Other SUNYConnect libraries held subscriptions totaling 153 (53.9\%) of the API titles, ninety-six of which were not held by the UA libraries.

Table 3 summarizes the total number of API titles that would be available to UA patrons if the libraries' own print subscriptions were included with the additional titles provided by each of the four full-text database products, the Empire Express, and the SUNYConnect resourcesharing arrangements. Table 4 shows the total number of API titles that would be available to UA patrons under both resource-sharing arrangements, in combination with each of the four full-text electronic products examined in this study.

\section{Discussion}

Examination of the four full-text electronic databases considered in this study revealed that none seem to offer a par-

\begin{tabular}{|c|c|c|c|}
\hline \multicolumn{4}{|c|}{$\begin{array}{l}\text { TABLE } 2 \\
\text { API Titles Held Locally and by Other Consortia Member Libraries } \\
\end{array}$} \\
\hline & $\begin{array}{l}\text { No. of } \\
\text { APITitles }\end{array}$ & $\begin{array}{c}\% \text { of } \\
\text { Total } A P I \text { Titles }\end{array}$ & $\begin{array}{l}\text { Titles in Addition to } \\
\text { UA Library Holdings }\end{array}$ \\
\hline UA Libraries & 62 & 21.8 & - \\
\hline $\begin{array}{l}\text { Other Empire Express } \\
\text { libraries }\end{array}$ & 135 & 47.5 & 78 \\
\hline $\begin{array}{l}\text { Other SUNYConnect } \\
\text { libraries }\end{array}$ & 153 & 53.9 & 96 \\
\hline
\end{tabular}


TABLE 3

Coverage of $A P I$ Titles by Full-Text Database and Consortia in Combination with UA Print Subscriptions

\begin{tabular}{lcc}
\hline \hline & No. of $A P I$ Titles & \% of Total API Titles \\
\hline EBSCO Academic Search FullTEXT Elite & 82 & 28.9 \\
Expanded Academic ASAP & 81 & 28.5 \\
Lexis-Nexis Academic Universe & 74 & 26.1 \\
ProQuest Direct & 74 & 26.1 \\
Empire Express & 140 & 49.3 \\
SUNYConnect & 158 & 55.6 \\
\hline
\end{tabular}

ticularly effective mechanism for expanding access to materials offering alternative points of view to UA patrons. At best, EBSCO Academic Search FullTEXT Elite covers twenty API titles beyond the sixtytwo print periodical subscriptions held by the UA libraries. Furthermore, given the considerable overlap of API titles covered by the full-text products, adding more than one of the database packages would provide diminishing returns. For example, if the UA libraries subscribed to all four commercial full-text products, the libraries' access would be increased only

The two-resource sharing programs examined in this study could serve to greatly expand access to alternative literature for UA patrons.

by another thirty-two titles beyond the sixty-two print subscriptions they hold currently. Of course, for smaller libraries that subscribe to very few print $A P I$ titles, adding EBSCO Academic Search FullTEXT Elite or Expanded Academic ASAP would at least give their patrons access to about 12 percent of the alternative literature under discussion.

A. Craig Hawbaker and Cynthia K. Wagner looked at full-text coverage of business journals in various electronic products. ${ }^{15}$ They found that, on average, the titles that are included in full-text databases tend to be the less costly ones. Our study did not address the pricing structure of the API titles, which is one possible reason why certain titles appear more frequently than others in the full-text prod- ucts. Other possibilities include the willingness of the publisher to license the titles or the relevance of the particular title to the selection criteria of the database vendor. Whether vendors and publishers of full-text packages will favor the inclusion of these titles remains to be seen.

Also, our study did not address completeness of coverage of the titles in the databases examined. Title counts were produced from the source lists prepared by the vendor. If a source purported to be full text, it was counted and no attempt was made to verify the completeness or reliability of any vendor's claims by testing the databases. Others have looked at the actual presence of sources within the full-text products and have found that the product advertising claims do not always match the actual content of a particular database. Ruth M. Orenstein examined full-text databases offered by several different vendors and found errors, missing issues (or even years), and substantial variation in coverage, editorial policy, and the treatment of tabular material. ${ }^{16}$ She also found that journal issue dates are often inconsistent within a product, with some full-text products having certain articles appear before the corresponding print publication comes out and some more than a year behind. Title changes, where both titles are retained on the product's source list, make these databases look as though they cover more publications than they do. Anna Grzeszkiewicz and A. Craig Hawbaker reported similar findings for a full-text business database. ${ }^{17}$ They noted that some items would actually "disappear" from the database over 
time, which has implications for collection building, but also for scholars attempting to cite or verify an apparently ephemeral article.

The two resource-sharing programs examined in our study could serve to greatly expand access to alternative literature for UA patrons. As shown in table 2, the existing Empire Express system provides access to another seventy-eight titles beyond the sixty-two owned by the UA libraries, for a total coverage of 49.3 percent. The figures are more impressive for the proposed SUNYConnect arrangement, which should allow patron access to another ninety-six titles, or a total coverage of 55.6 percent of the titles indexed by API. Were the University at Albany to participate in both SUNYConnect and Empire Express, patrons would have potential access to an additional ninety-nine API titles.

The SUNYConnect project is still in the developmental stages. This study examined the collective holdings of all SUNY libraries. However, participation by SUNY institutions is voluntary, and it is unknown how many libraries will eventually decide to join SUNYConnect. Further, it may be possible that some non-SUNY institutions also may be allowed to participate in the arrangement. Thus, these results may be somewhat different from the eventual universe of $A P I$ titles covered by SUNYConnect.
When considering alternate methods of access, both full-text databases and interlibrary loan within resource-sharing networks have some potential disadvantages over local ownership of a title. As noted above, availability of tabular data or graphics may be limited or nonexistent in full-text databases. Traditional ILL may not be timely enough for some requesters, particularly undergraduate students. Immediate access to electronic information has raised expectations and has made the delays associated with ILL less palatable.

Resource-sharing networks attempt to expedite delivery of documents to requesters from member libraries and thus reduce unacceptable delays. For example, the Empire Express system aims to provide documents to patrons within five working days. In her study of ILL costs, fill rate, and user satisfaction, Cheryl B.Truesdell reported that the best response time comes from state networks. ${ }^{18}$ It is important to note, however, that providing expedited ILL service within a network requires an added commitment of resources by participating institutions. In the case of SUNYConnect, it remains to be seen whether additional resources will be available at the institutional level to fund enhanced ILL service.

Participation in resource-sharing networks such as Empire Express and SUNYConnect offers opportunities for

\section{TABLE 4}

Coverage of $A P I$ Titles Provided by Full-Text Databases in Combination with UA and Consortia Print Subscriptions

\begin{tabular}{|ccccc}
\hline \hline & $\begin{array}{c}\text { Total API Titles } \\
\text { for UA+ } \\
\text { Empire Express }\end{array}$ & $\begin{array}{c}\text { \% of Total API } \\
\text { Titles }\end{array}$ & $\begin{array}{c}\text { Total API Titles } \\
\text { for UA + } \\
\text { SUNYConnect }\end{array}$ & $\begin{array}{c}\text { \% of Total } \\
\text { API Titles }\end{array}$ \\
\hline $\begin{array}{l}\text { EBSCO Academic } \\
\text { Search FullTEXT } \\
\text { Elite }\end{array}$ & 145 & 51.1 & 161 & 56.7 \\
$\begin{array}{c}\text { Expanded } \\
\text { Academic ASAP }\end{array}$ & 143 & 50.4 & 159 & 56.0 \\
$\begin{array}{c}\text { Lexis-Nexis } \\
\text { Academic Universe }\end{array}$ & 143 & 50.4 & 159 & 56.0 \\
ProQuest Direct & 143 & 50.4 & 160 & 56.3 \\
\hline
\end{tabular}


cooperative collection development projects to maximize access to currently held nonmainstream print journals. Alternative press journals may be among those most susceptible to cancellation because they may not be perceived as "scholarly," do not have high usage rates, or do not fare well in citation studies. Although some duplication of titles is probably necessary due to local academic program requirements, cancellation projects could be done more cooperatively to prevent the elimination of titles from the entire network. Moreover, it is important to note that because of licensing restrictions, the full-text databases generally cannot be used to produce documents for interlibrary loan. Findings from this study suggest that for nonmainstream periodical access, and presumably other emerging subject areas, print subscriptions may need to be maintained regardless of electronic full-text periodical title inclusion. Therefore, the presence of an electronic full-text periodical title should not be the sole criterion motivating periodical title cancellations.

\section{Conclusion}

Collecting materials representing a broad range of viewpoints, even highly controversial viewpoints, has long been an accepted democratic principle informing the library profession. Promoting diversity in the collection involves the inclusion of materials covering new theories and emerging disciplines. The prevalence of the API in ARL academic libraries suggests that nonmainstream literature is of value to the academic community. Factors such as usage, citation rates, and inclusion by indexing and abstracting services weigh heavily in libraries' decisions regarding periodical subscriptions. To the extent that nonmainstream journals as a genre reflect new perspectives or topical areas and tend to have considerably shorter life histories than journals presenting more mainstream points of view, they have a difficult task breaking into a tight fiscal environment. Periodical freezes and cancellations adversely affect access to more recent research and emerging disciplines. For example, most feminist academic journals have been started within the past thirty years. The difficulties that libraries have in finding funds to add even core feminist journals is magnified for those that are nonmainstream and can result in disproportionate access to certain viewpoints.

Academic librarians are familiar with the ongoing debate of access versus ownership. Laura Townsend Kane has argued that a "successful library of the future will consist of a delicate balance between materials that are owned and those that are accessed. The quality of these future libraries will not be determined by size but, rather, by how effectively they fulfill the needs of the patron." ${ }^{19}$ Although the authors acknowledge that there are advantages to providing full-text electronic databases, the reality is that alternative materials are not well represented in the commercial products available today. Therefore, libraries are currently dependent upon print subscriptions and participation in resource-sharing networks to maximize access to alternative or nonmainstream materials.

This study has shown that for the UA libraries, subscriptions to certain electronic full-text packages do not substantially increase access to titles covered by API. The findings also show that there is substantial overlap in periodical coverage among vendors who offer full-text periodicals. For libraries without print subscriptions to alternative materials, the full-text packages could be of some benefit in this regard. However, librarians concerned with ensuring diversity need to be cognizant of the content of full-text subscription packages.

For the UA libraries, participation in the Empire Express resource-sharing network clearly provides access to a much larger number of titles. The proposed SUNYConnect network, if fully implemented, could further expand the number of accessible titles. Currently, print subscriptions accessible through resource-sharing consortia and expedited interlibrary loan provide the best method of expanding access for API titles. 
The applicability of this study's findings to academic libraries in general depends, to some extent, on how representative the UA libraries' holdings of nonmainstream titles is in comparison to other academic libraries. It also depends on whether the resource-sharing consortia examined are representative of other local networks available to academic libraries. Academic libraries that decide to replicate this study may arrive at a considerably different result depending on their individual circumstances. However, the process used in this study should be helpful for librarians attempting to evaluate the efficacy of various access strategies for periodical literature. Furthermore, the process should prove helpful not just for the genre of nonmainstream periodicals, but for other subject groupings of periodicals as well.

\section{Notes}

1. "Diversity in Collection Development: An Interpretation of the Library Bill of Rights," in Intellectual Freedom Manual (Chicago: ALA, 1996), 49-59.

2. Juris Dilevko and Kalina Grewal, "A New Approach to Collection Bias in Academic Libraries: The Extent of Corporate Control in Journal Holdings," Library and Information Science Research 19, no.4 (1997): 359-85; Rita A. Marinko and Kristin H. Gerhard, "Representations of the Alternative Press in Academic Library Collections," College \& Research Libraries 59 (July 1998): 363-71.

3. Martha Kyrilldou, Michael O'Connor, and Julia C. Blixrud, comp., ARL Statistics 19961997: A Compilation of Statistics from the One Hundred and Twenty-one Members of the Association of Research Libraries (Washington, D.C.: ARL, 1998), 9. $3-4$.

4. "Library Bill of Rights: The Policy," in Intellectual Freedom Manual (Chicago: ALA, 1996),

5. "Diversity in Collection Development: History," 56.

6. Ibid., 57.

7. 1940 Statement of Principles on Academic Freedom and Tenure and subsequent interpretive comments as agreed to by American Association of University Professors and the Association of American Colleges. Available online at: http://www.aaup.org/1940stat.htm.

8. Dave Harmeyer, "Potential Collection Development Bias: Some Evidence on a Controversial Topic in California," College \& Research Libraries 56 (Mar. 1995): 101-11; Robert L. Houbeck Jr., "Locked in Conversation: The College Library Collection and the Pluralist Society," Journal of Library Administration 17, no. 2 (1992): 99-131; Stephen L. Hupp, "The Left and Right: A Preliminary Study of Bias in Collection Development in Ohio Libraries," Collection Management 14, no. 1/2 (1991): 139-54; Stephen L. Hupp, "The Left and the Right: A Follow-up Survey of the Collection of Journals of Political Opinion in Ohio Libraries," Collection Management 18, no. 1/2 (1993): $135-52$. 85.

9. Dilevko and Grewal, "A New Approach to Collection Bias in Academic Libraries," 359-

10. Alternative Press Center. Available online at: http://www.altpress.org/.

11. Marinko and Gerhard, "Representations of the Alternative Press in Academic Library Collections," 363-71.

12. Ibid., 363.

13. State University of New York: Office of Library and Information Services. SUNYConnect. Available online at: http:/ / olis.sysadm.suny.edu/sunyconnect/about.htm.

14. The Alternative Press Center's Online Directory. Available online at: http:// www.altpress.org/direct.html.

15. A. Craig Hawbaker and Cynthia K. Wagner, "Periodical Ownership versus Fulltext Online Access: A Cost-Benefit Analysis," Journal of Academic Librarianship 22 (Mar. 1996): 105-9.

16. Ruth M. Orenstein, "'How Full is Full \' Revisited: A Status Report on Searching Full-Text Periodicals," Database 16 (Oct. 1993): 14-23.

17. Anna Grzeszkiewicz and A. Craig Hawbaker, "Investigating a Full-Text Journal Database: A Case of Detection," Database 19 (Dec. 1996): 59-62.

18. Cheryl B. Truesdell, "Is Access a Viable Alternative to Ownership?" Journal of Academic Librarianship 20 (Sept. 1994): 200-206.

19. Laura Townsend Kane, "Access vs. Ownership: Do We Have to Make a Choice?" College E Research Libraries 58 (Jan. 1997): 66. 